\title{
Areal Precipitation Estimation Using Satellite Derived Rainfall Data over an Irrigation Area
}

\author{
Mehmet Ali Akgül,a, Hakan Aksu',b,* \\ ${ }^{I}$ General Directorate of State Hydraulic Works, 06420 Çankaya/Ankara, Turkey \\ ${ }^{2}$ Department of Meteorological Engineering, Samsun University, 55060 Samsun, Turkey
}

${ }^{*}$ Corresponding author

\section{A R T I C L E I N F O A B S T R A C T}

Research Article

The average precipitation on the irrigation field can be estimated from the Meteorology Observation Stations by using spatial interpolation methods such as Thiessen polygon and isohyetal curves. However, the fact that precipitation doesn't occur homogenous in spatial scales, spatial interpolation methodologies need a large number of meteorology stations for more accurate results. In recent years, remote sensing methods have diversified to estimate precipitation. In this study, performance of the satellite-based precipitation data was assessed to determine areal precipitation over an irrigation area. This study was conducted over left bank irrigation area located in the Çukurova Plain of Turkey. Relationship between CHIRPS satellite based on monthly precipitation data and 4 meteorology stations' data were analyzed. Determination coefficients $\left(\mathrm{R}^{2}\right)$ of the stations were found between 0.64 and 0.77 , for point based comparison, $\mathrm{R}^{2}$ was calculated as 0.84 with Thiessen polygon method. It is concluded that the precipitation amount in the irrigated area can be estimated

Keywords: CHIRPS

Precipitation

as accurately as classical methods such as Thiessen polygon with satellite-based precipitation data.

Remote sensing

The lower seyhan plain

Thiessen polygon

mali.akgul@dsi.gov.tr

(iD)http://orcid.org/0000-0002-5517-9576|b@hakan.aksu@samsun.edu.tr

http://orcid.org/0000-0003-4686-7446

(c) (1) () This work is licensed under Creative Commons Attribution 4.0 International License

\section{Introduction}

Access to clean water is getting more difficult day by day due to climate change, unplanned urbanization, rapid increase in the world population and similar reasons. Clean water is essential not only as drinking water for humans but also as irrigation water for agriculture in meeting the main foodstuffs. Although $70 \%$ of the earth's surface is covered with water, $96.54 \%$ of this water is in oceans and seas, and the number of freshwater lakes corresponds to only $0.007 \%$ of the total amount of water (Shiklomanov, 1993). Due to the decrease in precipitation and the increase in evapotranspiration caused by increasing global temperatures, water resources are gradually decreasing, and these dry conditions are thought to limit the sustainability of regional water resources in the near, medium and long term (Turkes et al., 2020).

Because of this, climatic changes are taken into consideration when planning water structures and revisions are made in existing water structures. Open irrigation systems are converted into pressurized systems, wild irrigation methods are abandoned and drip irrigation methods become widespread.

Plant water consumption is estimated for daily, monthly and seasonal time intervals. Monthly crop water consumption values are used in calculating irrigation system capacity whereas daily crop water consumption values are used in determining irrigation time and irrigation interval. Seasonal plant water consumption values are used in calculating irrigation water to be stored (İpek, 2006). When estimating the irrigation water requirement, in addition to the calculation of the water consumption of the plant, it is necessary to precisely determine the precipitation falling on the irrigation area. Presently, point based precipitation data can be calculated by using various interpolation techniques. It can be thought that using precipitation data produced by remote sensing in calculating areal precipitation, especially in large irrigation areas, will increase accuracy in estimating irrigation water needs. In recent years remote sensing applications are widely used to determine hydrological cycle 
parameters such as evapotranspiration, soil moisture, precipitation in irrigation areas (Bastiaanssen et al., 1998; Allen et al., 2007). In this study, the performance of the remote sensing data, to calculate the spatial precipitation used for the estimation of the irrigation water requirement, is investigated. For this purpose, CHIRPS (The Climate Hazards Group Infrared Precipitation with Station) was used in monthly precipitation data.

In Pakistan, Ullah et al. (2019), compared daily, monthly, annual and long-term data of 4 separate satellite precipitation data, namely CHIRPS, MSWEP, PERSIANNCDR and TMPA, in 4 different climate zones, which are; semi-arid, humid, arid and extremely arid. They compared the data of 51 stations covering the period between 1998 and 2016. They estimated the correlation coefficient of the CHIRPS satellite estimates between 0.56 and 0.95 on annual basis over the regions.

In the North-East of Brazil, Paredes-Trejo et al. (2017) performed an assessment study of CHIRPS performance and found the correlation coefficient as 0.94 , using the data of 21 stations obtained between 1981 and 2013. However, CHIRPS estimations showed positive bias for low rainfall amounts and negative bias for high precipitation amounts on a monthly basis. As a result of the study, the CHIRPS data set found as applicable for Brazil except the semi-arid NorthEast region

In mainland China, Bai et al. (2018) conducted a study to investigate the accuracy of CHIRPS satellite precipitation data. As a result of their study, using the data of 2480 rainfall stations between 1981 and 2014, they found that CHIRPS performance was better over the regions with high rainfall than arid and semi-arid regions. They also found that CHIRPS data yielded better results in warm seasons rather than in winter, due to limited ability of CHIRPS' to detect snowfall. Rivera et al. (2018) carried out an assessment study in the central Andean region of Argentina, using the data of 57 rainfall stations covering the years 1987-2016, observed that CHIRPS performance is better in regions with the highest summer precipitation than the drier regions.

Aksu and Akgül (2020) conducted a performance assessment study of CHIRPS data over Turkey covering the years from 2008 to 2018 by 77 rainfall station data in daily, compared with ten-daily and monthly values. They found that the CHIRPS estimations were highly correlated at monthly and ten-day time scales, but the correlation decreased for daily estimations. They concluded that CHIRPS precipitation data can be used as an input for hydrometeorological analysis over Turkey.

In this study, the usability of CHIRPS satellite data in the planning of irrigation sites was examined in the Lower Seyhan Plain left bank irrigation area. Point and spatial precipitation data were compared on a monthly time scale using 4 Meteorology Observation Stations (MOSs) data and CHIRPS precipitation data between 2010 and 2017 over the study area. The appropriateness of monthly CHIRPS precipitation data for point and areal irrigation planning was evaluated.

\section{Study Area}

The Lower Seyhan Plain (ASO in Turkish acronomy) irrigation project is one of the largest irrigation projects of Turkey, which consists of two sections so called Tarsus
Plain and Yüreğir Plain. The construction works of ASO left bank irrigation, which is selected as the study area, started in 1956, completed in 1965, and put into operation in the same year. The borders of the irrigation area are the Seyhan river in the West, the Ceyhan river in the east and Adana-Ceyhan main road in the North (Figure 1). ASO left bank irrigation has a gross irrigation area of 103.288 ha. Total net irrigated area is 58.728 ha by the $27.593 \mathrm{~km}$ long water supply channel with a capacity of $10.6 \mathrm{~m}^{3} / \mathrm{s}$ separated from the dam body by the $18.550 \mathrm{~km}$ long water supply channel irrigating 53.268 ha area with a capacity of $90 \mathrm{~m}^{3} / \mathrm{s}$ (DSİ, 2014).

\section{Data and Methodology}

CHIRPS was developed jointly by the US geological service (USGS) and the California University Santa Barbara (UCSB) climate hazard group (Funk et al., 2015). CHIRPS is a gridded precipitation time series, available from 1981 to approximately the present, with near-global $50^{\circ} \mathrm{S}-50^{\circ} \mathrm{N}, 180^{\circ} \mathrm{E}-180^{\circ} \mathrm{W}$ and $0.05^{\circ}$ resolution.

\section{CHIRPS;}

- Monthly precipitation climatology (CHPCLIM)

- Infrared sensors of terrestrial satellites

- $\quad$ TRMM 3B 42 product

- Ground precipitation observations.

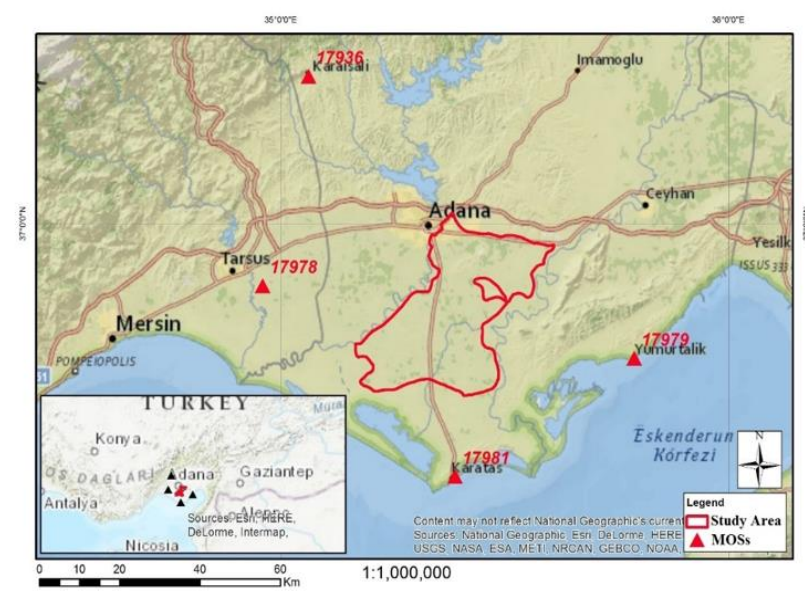

Figure 1. Study Area and Locations of The MOSs

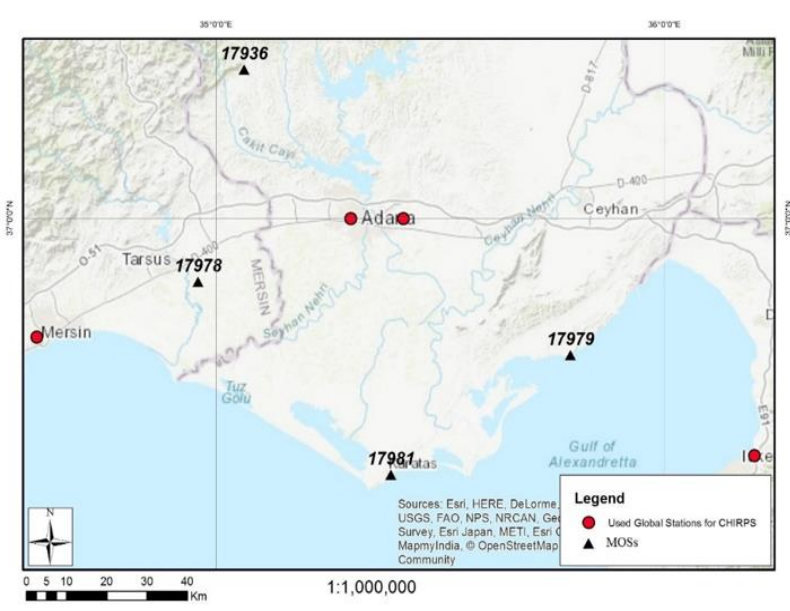

Figure 2. Location of Validation Stations 


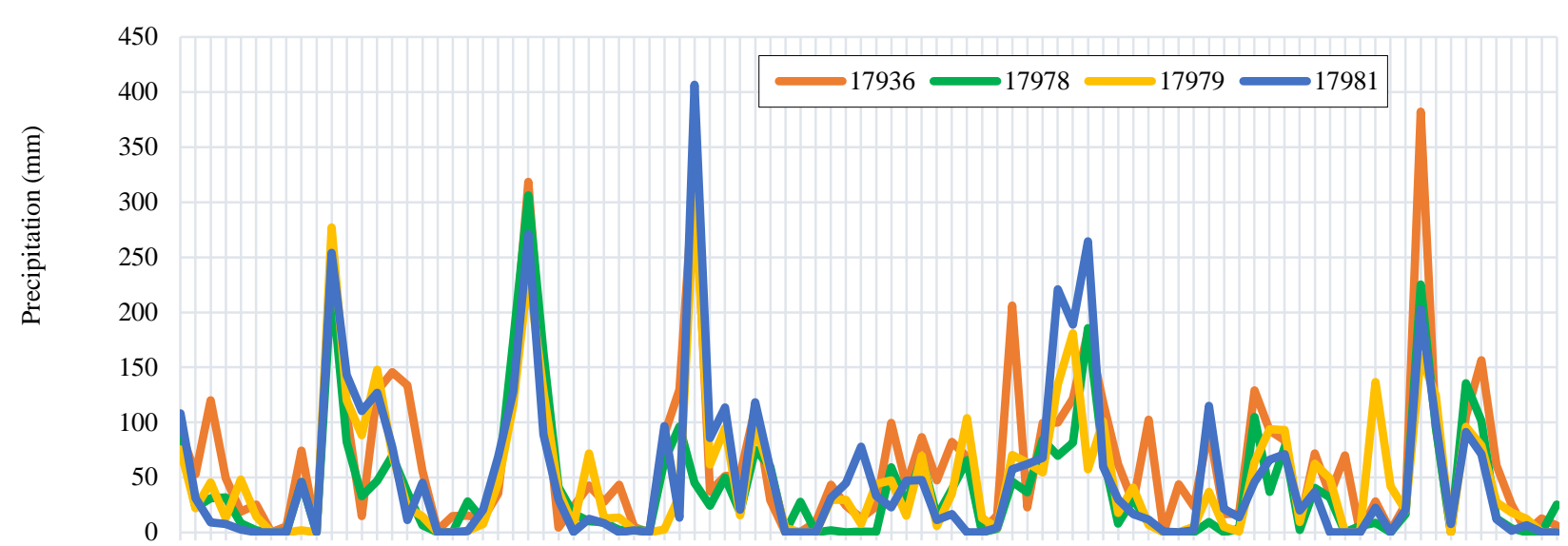

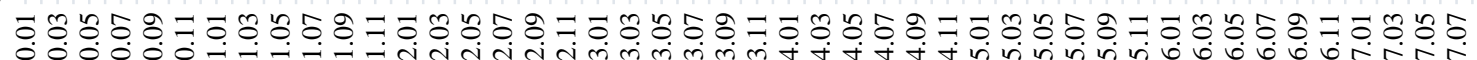

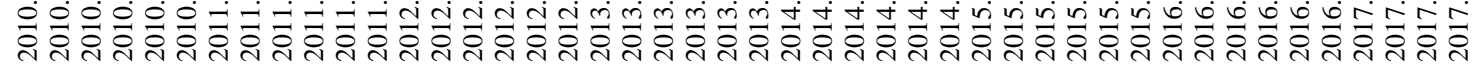

Time

Figure 3. Monthly Total Precipitation Data of MOSs

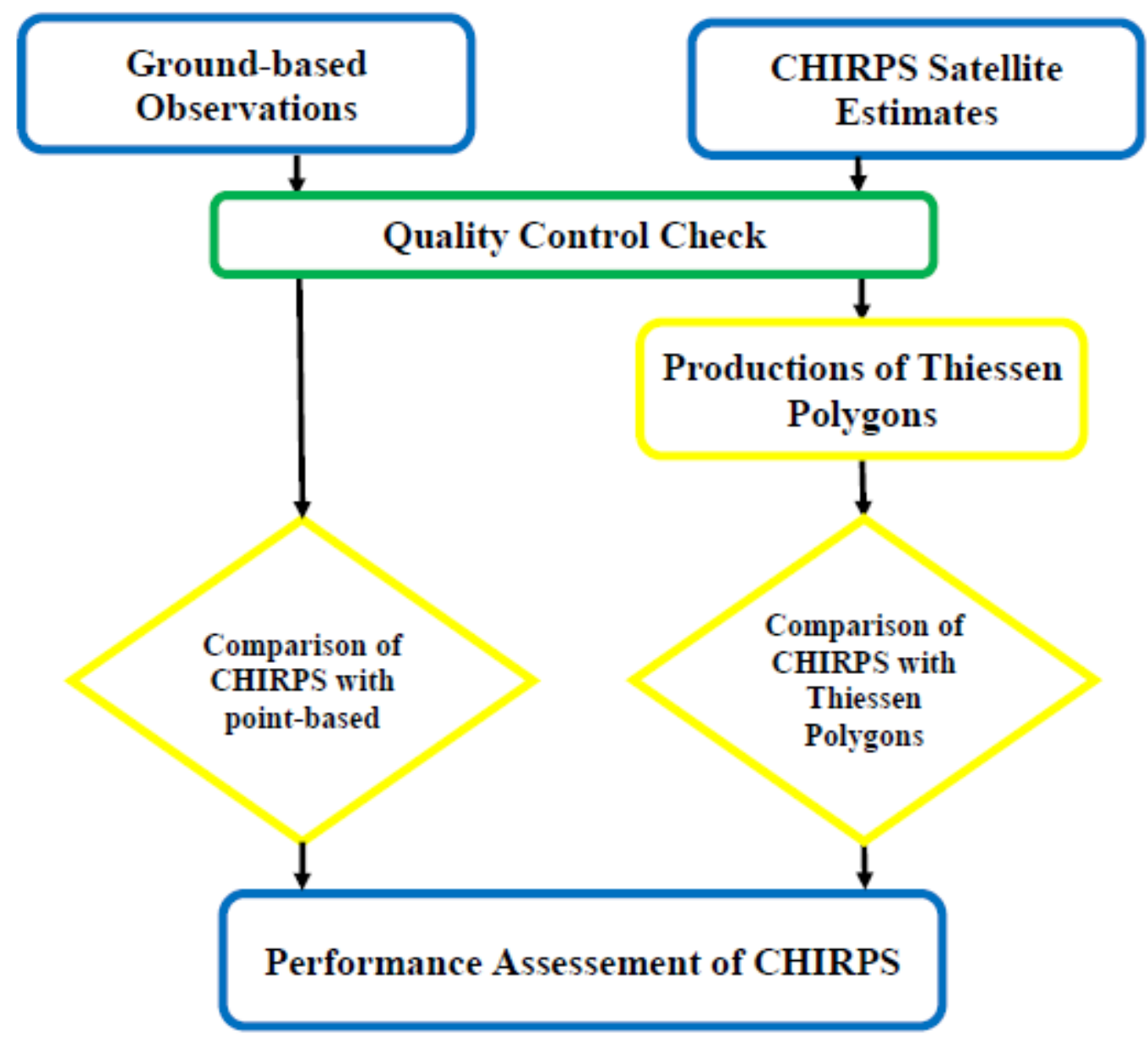

Figure 4. Flow Chart of Performance Assessment Procedure

CHIRPS data are generated at daily, 5-day, 10-day and monthly time resolutions with a spatial resolution of $0.05^{\circ}$ (approximately $5.3 \mathrm{~km}$ ). available for land surfaces only. The manufacturing process of the CHIRPS precipitation data set is based on regression models of 5-day cloud top temperatures and calibration with TRMM. The data set is then multiplied by precipitation climatology which is produced by groundbased meteorology stations (CHIRP). The last step is to blend it with ground stations (Tote et al., 2015)
Of the stations used in this blending process of the CHIRPS, 4 of them were located inside of the study area. These stations, shown with a red circle in Figure 2, were not used in comparison of performance. The CHIRPS data used in the study were downloaded from the website http://chg.geog.ucsb.edu/data/CHIRPS/ provided that it is in the same period with the data obtained from the Turkish State Meteorological Service (MGM). 
Monthly total precipitation values were obtained from MGM covering the years 2010-2017. The characteristics of the stations used are given in Table 1.

The highest total monthly rainfall values are measured as $382.20 \mathrm{~mm}$ at the Karaisal1 station in December 2015, $306.20 \mathrm{~mm}$ at the Tarsus station in January 2012, 317.40 $\mathrm{mm}$ at the Yumurtalık station in January 2010 and 406.80 $\mathrm{mm}$ at the Karataş station in December 2012 (Figure 3).

In this study, two different comparisons were performed as point-based precipitation and areal interpolated precipitation. Station rainfall data was compared with the CHIRPS data in the same pixel.

In the spatial method, the Thiessen Polygon was produced in the ArcMap program to cover the study area (Esri, 2011). The Thiessen polygon was developed as a simple method to overcome the uneven distribution of precipitation stations in a basin (Thissen, 1911). Thiessen polygon method can be applied to flat terrain with homogeneous precipitation climatology. The areal precipitation value using Thiessen's polygons is a weighted average weighted depending on the size of the area represented by each station (Davie, 2008). In general, this method is applied during the uneven distribution of stations in spatial scale (Burgan, 2019) (Formula 1).

$$
\mathrm{P}=\frac{\sum_{\mathrm{i}=1}^{\mathrm{N}} \mathrm{P}_{\mathrm{i}} \mathrm{A}_{\mathrm{i}}}{\mathrm{A}}
$$

P: Real average precipitation

Pi: The amount of precipitation measured at the station

Ai: The area represented by the station

A: The total area.
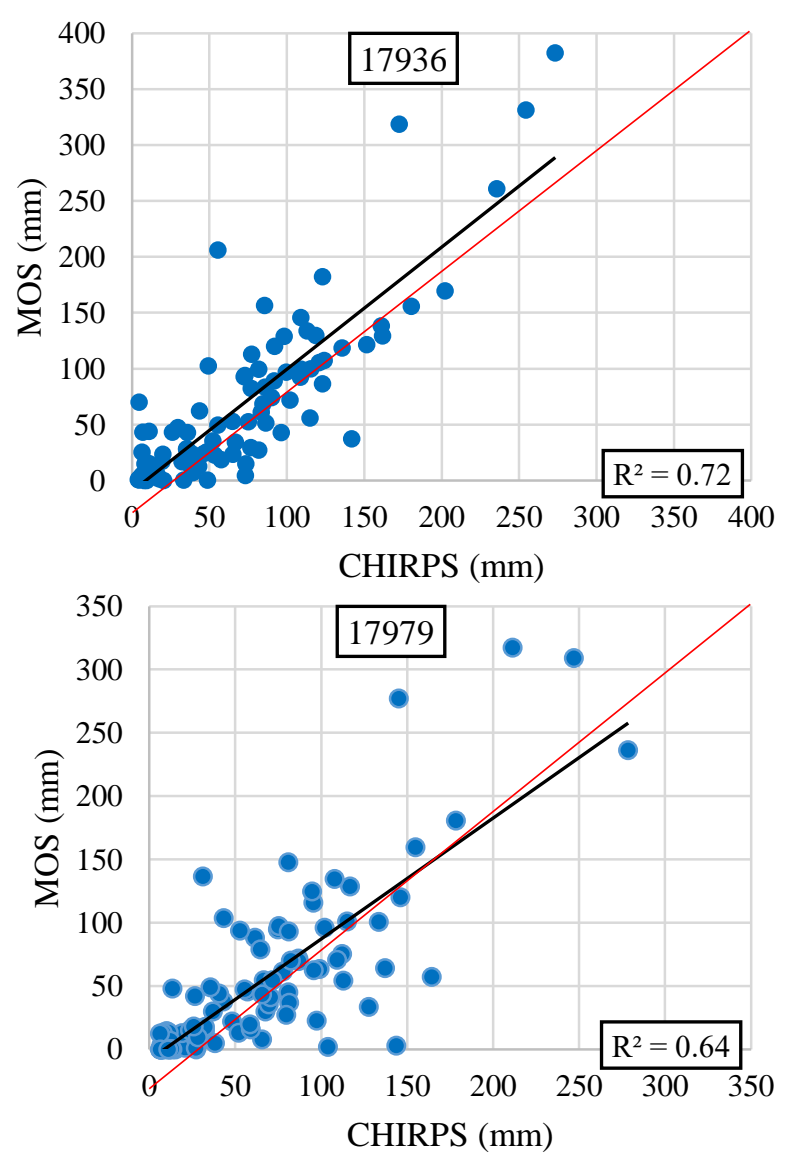

Thiessen polygons are plotted by using data points over a determined region and assumes representative all locations in that polygon to the closest member of the point set (Yamada, 2016). This technique is only valid when the topography is homogeneous within each polygon, so that the precipitation distribution within the polygon can be assumed with the same confidence (Davie, 2008). Thiessen polygon methods are widely used in hydrology. The main reason for common use of Thiessen Polygon is that the weights assigned to the stations do not change over time (unless the measuring network is changed during the considered period). Then, it is easy to estimate the average amount of precipitation over successive periods of a given period (Musy et al., 2014).

After the Thiessen polygons plotted and the values taken from the meteorology stations, the monthly total precipitation values in the study area were calculated. In addition, the average of 42 CHIRPS data cell values remaining in the study area was calculated. In order to facilitate the calculations made on cell values, Virtual Stations (VS) were produced, one at the geometric center of each cell. The correlation between the Thiessen polygon and the areal precipitation values found by VS method. Flow chart of applied methodology is presented in Figure 4.

Comparison statistics and formulas used in both point and areal correlation calculations are given in Table 2.

NSE (Nash-Sutcliffe Efficiency) determines the relative magnitude of the variance of residues compared to the variance of observed values and takes values between $\infty$ and 1. A NSE value of 1 indicates perfect fit, while negative values represent a weak association (Nash and Sutcliffe, 1970).
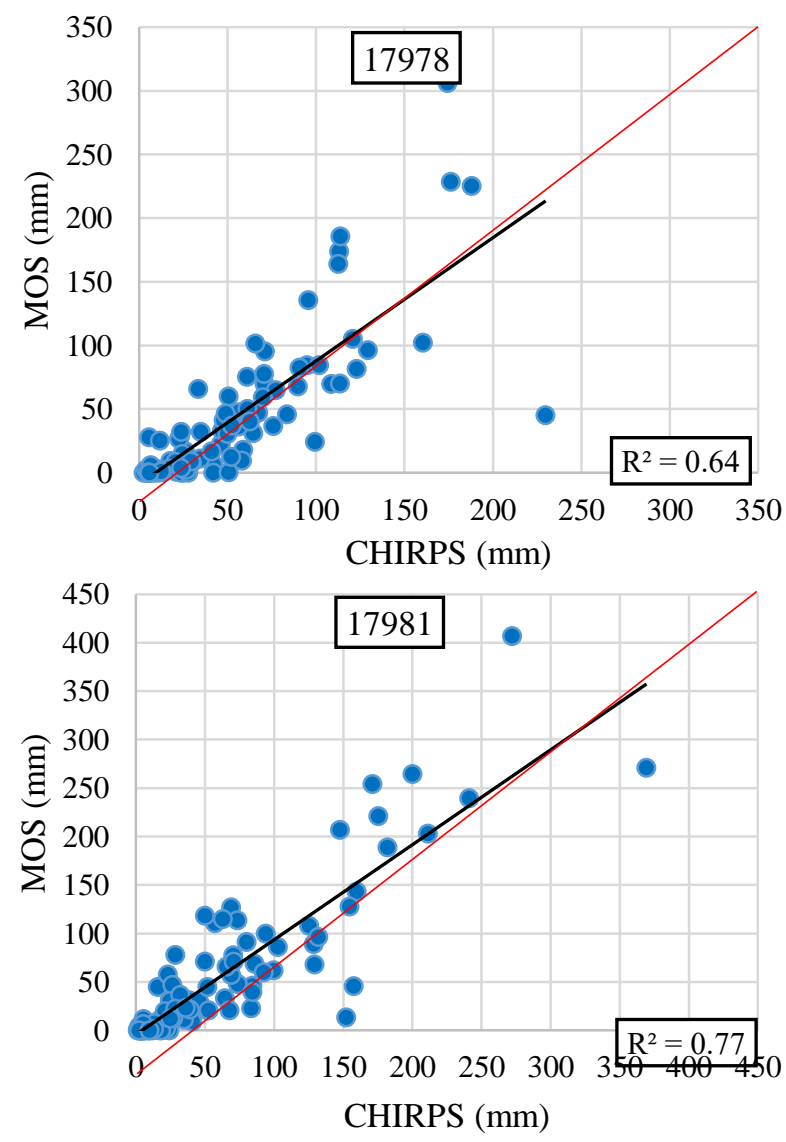

Figure 5. Correlation Graphs Between MOSs and CHIRPS Data 
The PBIAS statistic measures the tendency of the forecast data to the observation data. It shows that as the value of PBIAS approaches 0, the relationship between the prediction data and the observation data is high. Positive values indicate model underestimation bias and negative values indicate model overestimation bias (Gupta et al., 1999).

Pearson Correlation Coefficient (r) shows the degree of relationship between observed values and predicted values, and ranges between -1 and 1 . Zero means that there is no relationship. The determination coefficient $\left(\mathrm{R}^{2}\right)$ is the square of $r$, which is the Pearson Correlation Coefficient. It takes a value between 0 and 1 . As this value approaches 1 , it means a high relationship between the observed value and estimated values.

While it is acceptable for $\mathrm{R}^{2}$ and $\mathrm{r}$ statistics to take a value greater than 0.5 (Liew et al., 2003), acceptable values for PBIAS and NSE statistics are given in Table 3.

\section{Results and Conclusion}

The values of the CHIRPS data grids corresponding to the meteorology stations were calculated, and the relationship between the measured monthly total precipitation values are given in Figure 5. When the graphs are examined, it is seen that the deviation is more for high precipitation.

In the correlation analysis between meteorology station data and CHIRPS, the best result was obtained for Karataş meteorology station, which represents the study area at the highest rate, as can be seen in the Thiessen polygon given in Figure 6. Thiessen polygons of the stations were calculated as
$4.20 \%$ for Karaisalı station, $12.32 \%$ for Tarsus station, $22.22 \%$ Yumurtalık station and $61.25 \%$ Karataş station (Figure 6). The graph of CHIRPS data and interpolated rainfall data by Thiessen polygon is given in Figure 7, and the correlation between them is given in Figure 8. As a result of the regression analysis, the $\mathrm{R}^{2}$ value was found as 0.84 .

NSE, PBIAS, $r$ and $\mathrm{R}^{2}$ statistics between CHIRPS data and measured values were given in Table 4 (Clophas and Zwinderman, 2016).

According to the statistical evaluation, the results were acceptable since the $\mathrm{r}$ and $\mathrm{R}^{2}$ statistics were higher than 0.5 for each station. According to the NSE statistics threshold values given in Table 3; stations 17978 and 17979 were sufficient, stations 17936 and 17981 were good, and the Thiessen polygon method was very good. When the results of the PBIAS statistics were examined, it was seen that station 17978 was insufficient, station 17979 was sufficient, station 17981 was good, and the Thiessen polygon method was very good. Although the Thiessen polygon method gave the second-best result in PBIAS statistics, it was seen that it gave the best result in other statistics.

The maximum monthly precipitation was recorded in December 2012 in the study period over the study area (Figure 9). Delineated area by Thiessen polygon method covers 27 pixels of the CHIRPS product and ranging from $193.74 \mathrm{~mm}$ to $231.23 \mathrm{~mm}$. In the case of Thiessen methodology, areal precipitation defined as $272.37 \mathrm{~mm}$ (only one value rather than 27 pixels) by Karataş MOS. For the better representation of precipitation distribution in spatial extent, CHIRPS has superiority over the Thiessen Polygon methodology.

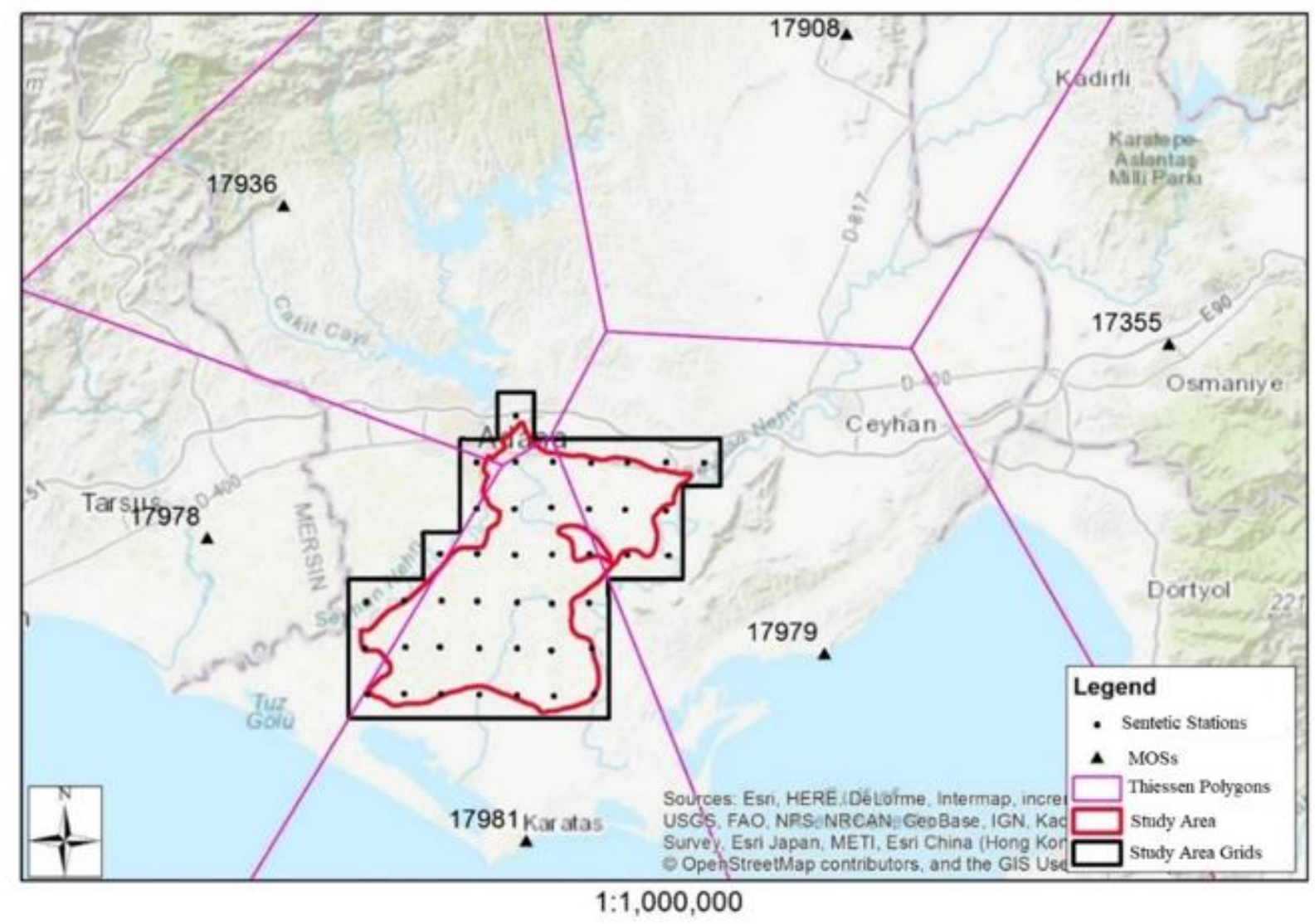

Figure 6. Thiessen Polygons of the Study Area 


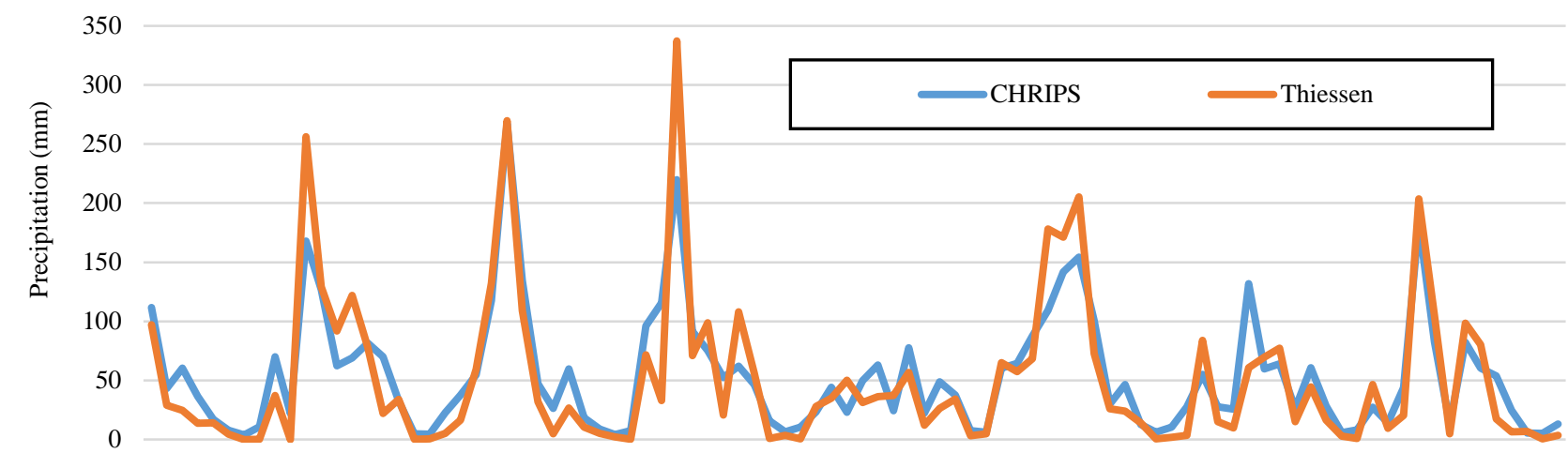

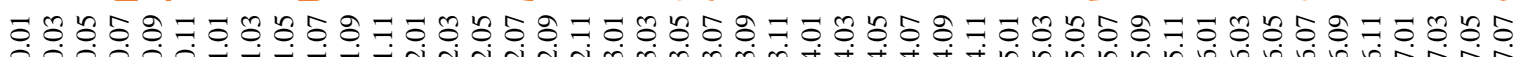

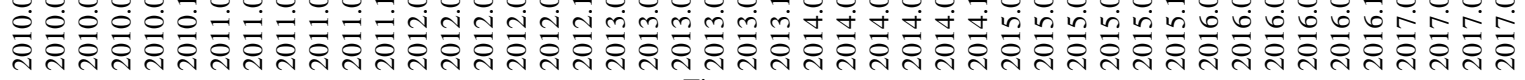
Time

Figure 7. Comparison of Thiessen Polygon and CHIRPS Data

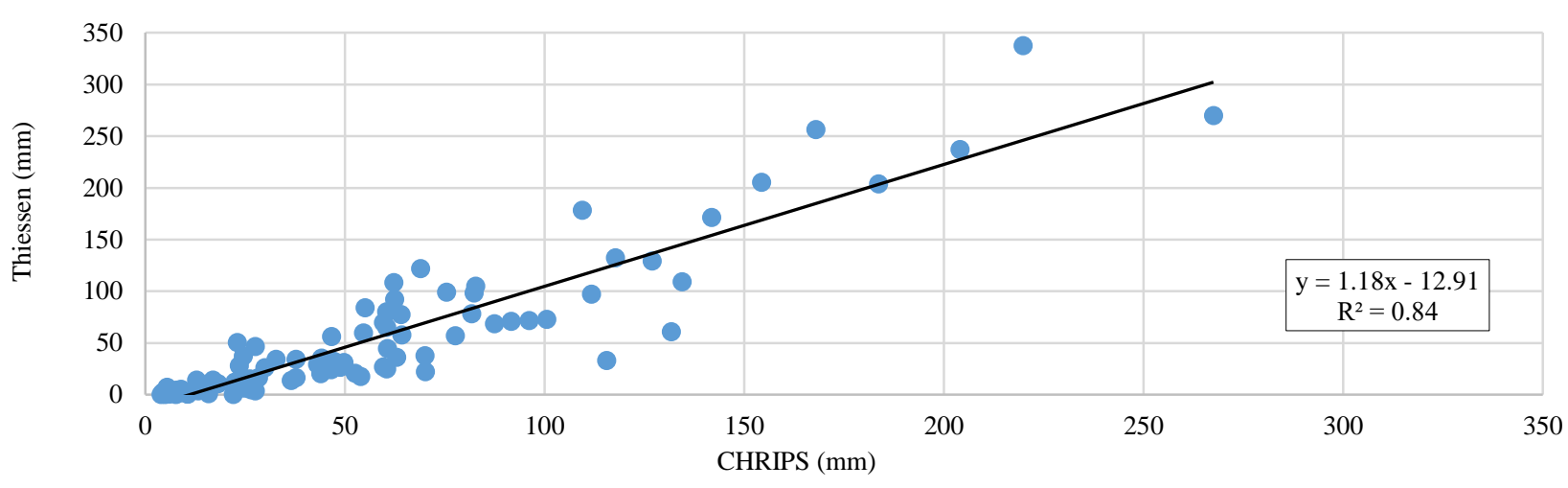

Figure 8. Correlation Graph Between Thiessen Polygon and CHIRPS Data

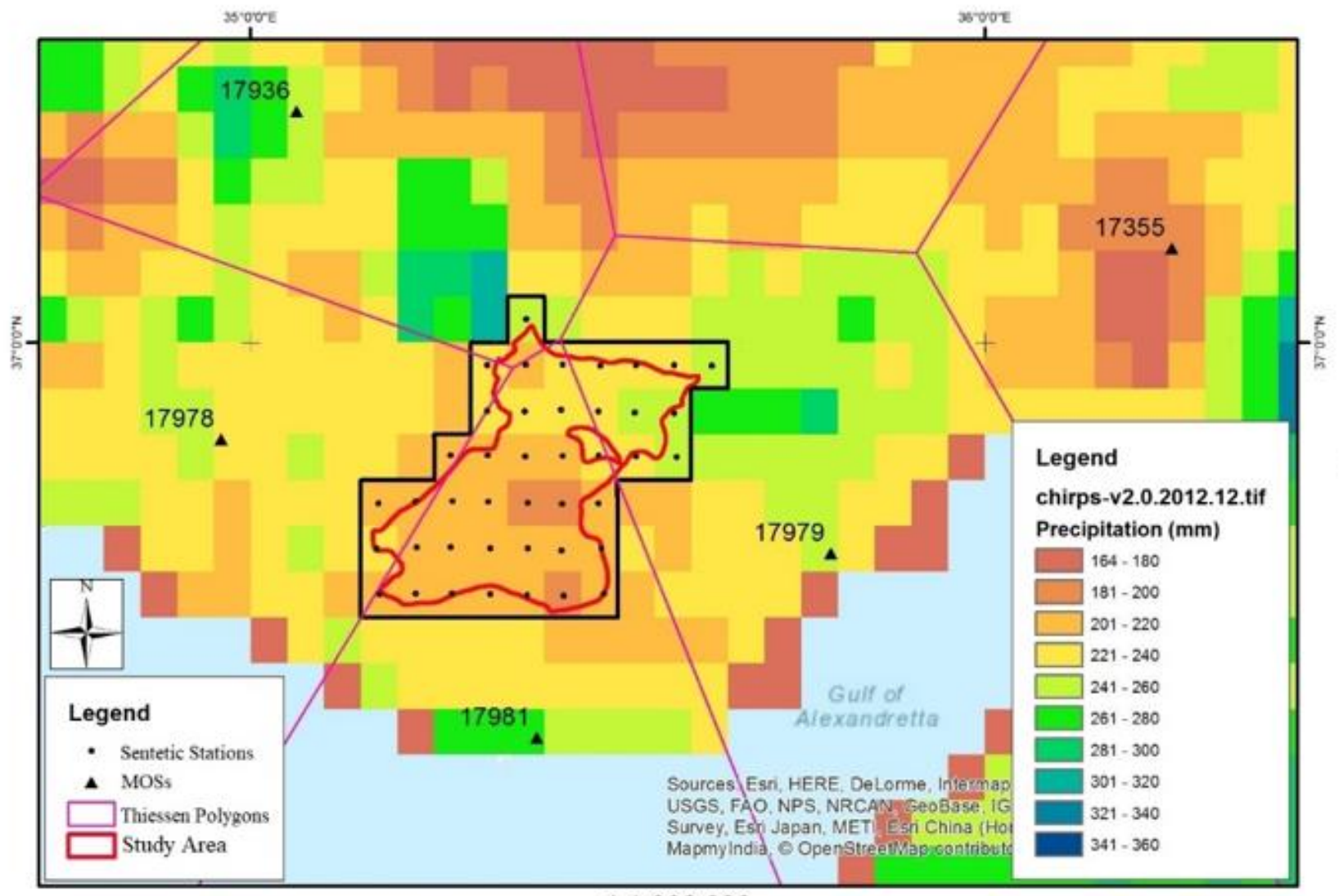

$1: 1,000,000$

Figure 9. Thiessen Polygon and CHIRPS Data for December 2012 


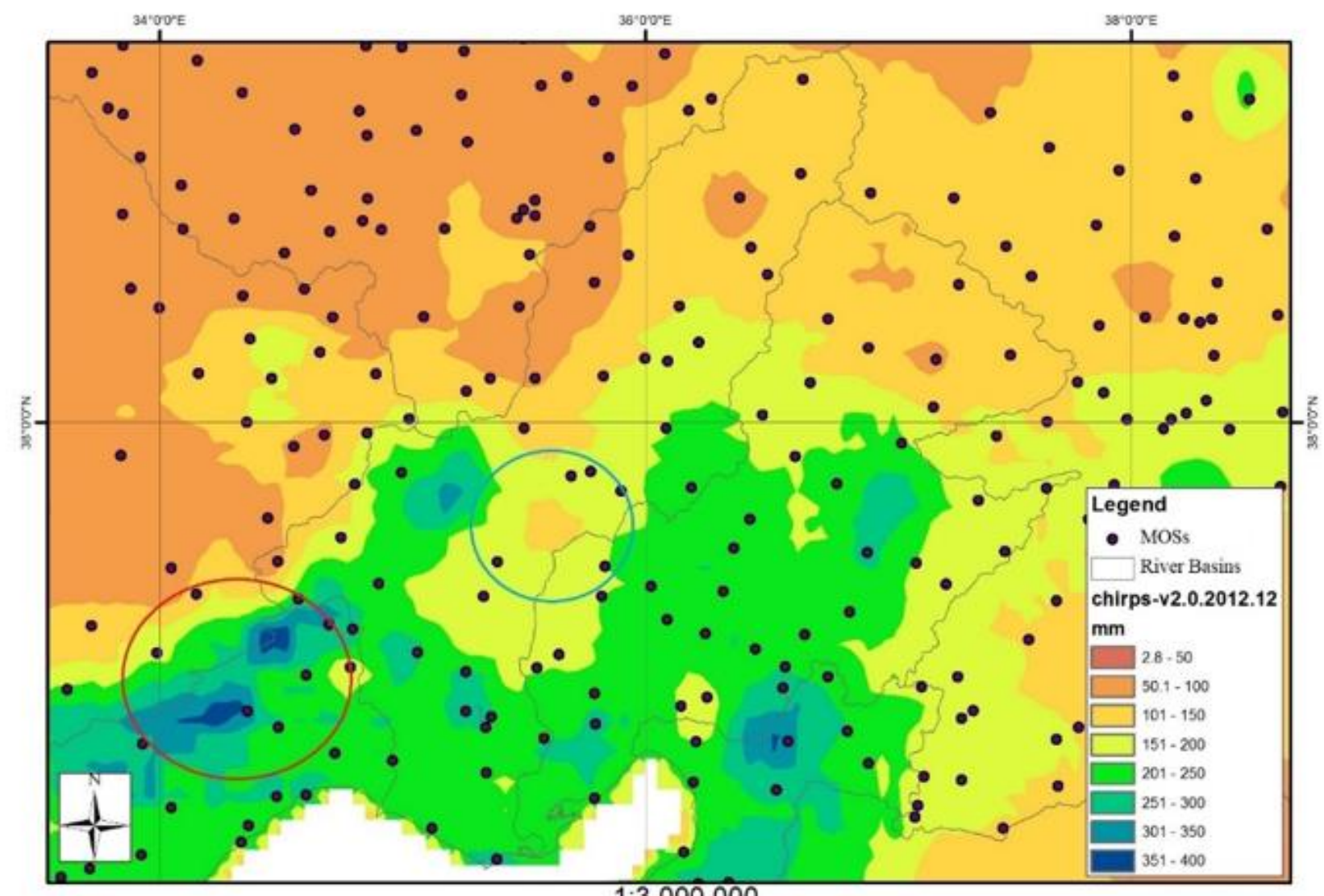

$1: 3,000,000$

Figure 10. MOSs in The Region and CHIRPS Data for December 2012

Table 1. Characteristics of Validation Stations

\begin{tabular}{l|ccccccc}
\hline No & Stations No & Stations Name & County & Town & North $\left(^{\circ}\right)$ & East $\left({ }^{\circ}\right)$ & Elevation $(\mathrm{m})$ \\
\hline 1 & 17936 & Karaisalı & Adana & Karaisalı & 37.2506 & 35.0628 & 240 \\
2 & 17978 & Tarsus & Mersin & Tarsus & 36.8942 & 34.9597 & 12 \\
3 & 17979 & Yumurtalık & Adana & Yumurtalık & 36.7687 & 35.7903 & 34 \\
4 & 17981 & Karataş & Adana & Karataş & 36.5683 & 35.3894 & 22 \\
\hline
\end{tabular}

Table 2. Formulas of Comparison Statistics

\begin{tabular}{l|c}
\hline \multicolumn{1}{c|}{ Statistics } & Formula \\
\hline Nash-Sutcliffe Efficiency Coefficient & $N S E=1-\frac{\sum_{i=1}^{N}\left(C_{i}-G_{i}\right)^{2}}{\sum_{i=1}^{N}\left(G_{i}-\breve{G}\right)^{2}}$ \\
PBIAS & $P B I A S=100 \frac{\sum_{i=1}^{N}\left(C_{i}-G_{i}\right)}{\sum_{i=1}^{N} G_{i}}$ \\
Pearson Correlation Coefficient & $r=\frac{\sum_{i=1}^{N}\left(G_{i}-\breve{G}\right)\left(C_{i}-\tilde{C}\right)}{\sqrt{\left(G_{i}-\breve{G}\right)^{2}} \sqrt{\left(C_{i}-\dot{C}\right)^{2}}}$ \\
\hline
\end{tabular}

$\overline{\mathrm{G}}=$ Measured precipitation amounts, $\overline{\mathrm{G}}=$ Average of measured precipitation amounts, $\mathrm{C}=\mathrm{CHIRPS}$ values, $\mathrm{C}^{\prime}=$ Average of $\mathrm{CHIRPS}$ values and $\mathrm{N}=$ Number of data pairs

Table 3. General Performance Evaluation for Statistical Results (Moriasi et al., 2007)

\begin{tabular}{l|cc}
\multicolumn{1}{c}{ Performance Measure } & NSE & PBIAS $(\%)$ \\
\hline Very good & $0.75<\mathrm{NSE} \leq 1.0$ & PBIAS $< \pm 10$ \\
Good & $0.65<\mathrm{NSE} \leq 0.75$ & $\pm 10 \leq$ PBIAS $< \pm 15$ \\
Enough & $0.50<\mathrm{NSE} \leq 0.65$ & $\pm 15 \leq$ PBIAS $< \pm 25$ \\
Insufficient & NSE $\leq 0.50$ & PBIAS $\geq \pm 25$ \\
\hline
\end{tabular}


Table 4. Statistical Tests Results between CHIRPS and Stations and Areal Precipitation

\begin{tabular}{l|cccc}
\hline \multicolumn{1}{c|}{ Station No } & NSE & PBIAS (\%) & r & $\mathrm{R}^{2}$ \\
\hline 17936 & 0.72 & 4.82 & 0.85 & 0.72 \\
17978 & 0.60 & 25.42 & 0.80 & 0.64 \\
17979 & 0.61 & 21.05 & 0.80 & 0.64 \\
17981 & 0.77 & 10.26 & 0.88 & 0.77 \\
Thiessen & 0.82 & 5.71 & 0.92 & 0.84 \\
\hline
\end{tabular}

As an example, CHIRPS data of December 2012 with its high precipitation amount is shown in Figure 10 and there is no station over the marked area with $350-400 \mathrm{~mm}$ precipitation. During the interpolation of point data, this maximum precipitation wouldn't be depicted.

Red marked area corresponds to the basin of Berdan and Pamukluk dam, which lies $50 \mathrm{~km}$ North of Mersin Province. Although these high rainfalls were detected from CHIRPS satellite data, they could not be detected by MOSs. The inability to detect these precipitation causes a problem for the operation of these dams for irrigation and flood purposes, and it was concluded that the CHIRPS satellite data can also be used in the dam operation.

Blue marked zone corresponds to the basin of Köprü Dam and HEPP, which is located $75 \mathrm{~km}$ North-West of Adana province. According to the CHIRPS data, this region received less rainfall than the MOSs measured. It was concluded that the CHIRPS data could be used in the operation of hydroelectric power plants other than the dam operation.

In studies using monthly total rainfall data, it has been observed that MOSs may be insufficient. It is thought that when a new MOS is to be established or when an established MOS is to be relocated, monthly total rainfall maps produced from CHIRPS data can be used.

CHIRPS satellite data has a spatial resolution of $0.05^{\circ}$, i.e., a cell size of about $5.3 \mathrm{~km}$. This means that data can be received on an area of approximately $28 \mathrm{~km}^{2}$. It is extremely difficult to establish and operate MOS at this frequency and is unlikely to be profitable in cost-benefit analysis. Therefore, in parallel with the developing technology, the availability of satellite-based precipitation data in flood and irrigation, planning and projecting studies is very important in terms of cost and time. In this study, we tried to find an answer to the question of whether satellite-based precipitation data can be used in irrigation planning.

As a result of the study, the correlation between the CHIRPS data and the measurements of MOSs and Thiessen polygon values were examined. NSE, PBIAS, $r$ and $\mathrm{R}^{2}$ statistics, which are frequently used in statistical studies, were used to determine this correlation. As a result of the calculations, Thiessen polygon method gave the best result with 0.82 according to NSE statistical values. When the results of the PBIAS statistics were examined, the station number 17978 was insufficient with $25.42 \%$, and the Thiessen polygon method gave the second-best value after the station 17936 with $5.71 \%$. Even if station number 17978 was statistically insufficient, the Thiessen polygon method was able to eliminate it spatially. Thiessen polygon method gave the highest result in $\mathrm{r}$ and $\mathrm{R}^{2}$ statistics, and they were found as 0.92 and 0.84 , respectively.
As a result of the study, the following issues were determined:

- For monthly analysis, when monthly precipitation values are high, it has been observed that the satellite precipitation data shows negative BIAS. Considering that the need for irrigation water will be higher in months with low precipitation values, it can be evaluated that the effect of the deviation in high precipitation will be limited in the determination of irrigation water.

- It has been concluded that high accuracy can be achieved by directly using CHIRPS satellite data instead of processes such as operating the MOS, evaluating the data, creating the Thiessen polygon, and calculating the monthly total rainfall in the study area.

- When a new MOS will be established or when an available MOS will be relocated, it is considered that precipitation maps produced from CHIRPS satellitebased precipitation data can be used. It has been observed that it can be used at the point where it can be detected especially in precipitation that cannot be detected by the stations.

- It has been observed that CHIRPS, one of the satellite precipitation products, has reached the stage of producing data at a usable level in other applications of hydrometeorology (drought analysis, basin water budget calculations, determination of daily maximum precipitation).

\section{Acknowledgements}

The authors would like to express their gratitude to the Turkish State Meteorological Service, Climate Hazard Group, and UCBS for providing the precipitation data used in this study.

\section{References}

Aksu H, Akgül MA. 2020. Performance evaluation of CHIRPS satellite precipitation estimates over Turkey, Theor Appl Climatol 142: 71-84, doi.org/10.1007/s00704-020-03301-5.

Allen RG, Tasumi M, Trezza R. 2007. Satellite-based energy balance for mapping evapotranspiration with internalized calibration (METRIC)-Model, J. Irrig. Drain. Eng, ASCE 133 (4): 380-394.

Bai L, Shi C, Li L, Yang Y, Wu J. 2018. Accuracy of CHIRPS Satellite-Rainfall Products over Mainland China, Remote Sens, 10: 362.

Bastiaanssen WGM, Menenti M, Feddes RA, Holtslag AAM. 1998. A remote sensing surface energy balance algorithm for land (SEBAL), 1. Formulation, Journal of Hydrology, Vol. 212-213: Pages 198-212.

Burgan Hİ. 2019. Flow Duration Curve Model for Ungauged Intermitted Rivers, Istanbul Technical University, $\mathrm{PhD}$ Thesis. 
Cleophas TJ, Zwinderman AH. 2016. SPSS for starters and 2nd levelers. Cham: Springer International Publishing, https://doi.org/10.1007/978-3-319-20600-4.

Davie T. 2008. Fundamentals of Hydrology, Second Edition, Routledge Fundamentals of Physical Geography Series, Taylor and Francis, London and New York.

DSİ, 2014. Seyhan River Basin Master Plan Report, 6th Regional Directorate, Adana.

Esri, 2011 ArcGIS Desktop: Release 10, Redlands, CA: Environmental Systems Research Institute.

Funk C, Verdin J, Michaelsen J, Peterson P, Pedreros D, Husak G. 2015. A global satellite assisted precipitation climatology, Earth System Science Data Discussions, 7: 1-13, https://doi.org/10.5194/essdd-7-1-2015.

Gupta H, Sorooshian V, Yapo PO. 1999. Status of Automatic Calibration for Hydrologic Models: Comparison with Multilevel Expert Calibration, J. Hydrologic Eng, 4(2): 135143.

İpek Şİ. 2006. Sulama, Su Vakfi, İstanbul.

Liew MWV, Arnold JG, Garbrecht JD. 2003. Hydrologic simulation on agricultural watersheds: Choosing between two models, Trans. ASAE 46(6): 1539-1551.

MGM, 2020. https://www.mgm.gov.tr/kurumsal/istasyon larimiz.aspx, Last accession date September 13: 2020.

Moriasi DN, Arnold JGM, Van Liew W, Binger RI, Harmel RD, Veith T. 2007. Model evaluation guidelines for systematic quantification of accuracy in watershed simulations, Transactions of the ASABE, 50(3): 885-900. doi: 10.13031/2013.23153.

Musy A, Hingray B, Picouet C. 2014. Hydrology. A Science for Engineers, Boca Raton: CRC Press, Taylor and Francis Group. https://doi.org/10.1201/b17169.
Nash JE, Sutcliffe JV. 1970. River Flow Forecasting through Conceptual Models 1. A Discussion of Principles, Journal of Hydrology, 10(3): 282-290.

Paredes-Trejo FJ, Barbosa HA, Kumar TVL. 2017. Validating CHIRPS-based satellite precipitation estimates in Northeast Brazil, J Arid Environ, 139: 26-40.

Rivera JA, Marianetti G, Hinrichs S. 2018. Validation of CHIRPS precipitation dataset along the Central Andes of Argentina, Atmospheric research, doi:10.1016/j. atmosres.2018.06.023.

Shiklomanov I. 1993. World fresh water resources. In: P.H. Gleick, editor. Water in crisis: A guide to the world's fresh water resources. Oxford Univ. Press, New York.

Thiessen AH. 1911. Precipitation Averages for Large Areas, Monthly Weather Review, 39(7): 1082-1084.

Tote C, Patricio D, Boogaard H, Wijngaart R Van Der, Tarnavsky E, Funk C. 2015. Evaluation of satellite rainfall estimates for drought and flood monitoring in Mozambique, Remote Sens, 7 (2): 1758-1776.

Turkes M, Turp MT, An N, Ozturk T, Kurnaz ML. 2020. Impacts of Climate Change on Precipitation Climatology and Variability in Turkey, In: Harmancioglu N, Altinbilek D (eds) Water Resources of Turkey, World Water Resources, Vol 2. Springer, Cham.

Ullah W, Wang G, Ali G, Tawia Hagan DF, Bhatti AS, Lou D. 2019. Comparing Multiple Precipitation Products against InSitu Observations over Different Climate Regions of Pakistan, Remote Sens., 11: 628.

Yamada I. 2016. Thiessen Polygons, The International Encyclopedia of Geography: John Wiley and Sons, Ltd. Published, doi:10.1002/9781118786352.wbieg0157. 